\title{
Solid Wastes Composition and Generation in Selected Hotels at Aba and Umuahia, Abia State, Nigeria
}

\author{
${ }^{1}$ CHIKWENDU, MU; *2 UCHENDU, UI; ${ }^{2} \mathrm{KANU}, \mathrm{C}$ \\ ${ }^{l}$ Department of Forestry and Environmental Management, ${ }^{2}$ Department of Environmental Management and Toxicology, Michael Okpara \\ University of Agriculture Umudike, Abia State, Nigeria \\ *Corresponding Author Email: udouche@yahoo.com; other emails: nwogwugwu.michael@gmail.com, and kanu.chidozie84@gmail.com
}

\begin{abstract}
A comparative study on solid wastes composition and generation in selected hotels in Umuahia and Aba metropolis of Abia state was conducted with a single factor experiment in randomized complete block design to determine the types and quantities of municipal solid waste generated at specific location in the two municipalities with three replications in both locations. The result shows Food/putrescible waste and glass/bottles are generated significantly higher than any other wastes types with mean values $(73.44 \mathrm{~kg}, 59.89 \mathrm{~kg} 58.77 \mathrm{~kg}, 54.61 \mathrm{~kg})$ and respectively in Aba and Umuahia city followed by plastic and polybags with significant low in inert and textile waste with mean value of $(14.4 \mathrm{~kg}$ $22.03 \mathrm{~kg})$ and $(13.12 \mathrm{~kg}, 17.28 \mathrm{~kg})$ in Umuahia and Aba respectively. The study recommend that waste should be sorted out into their various components at source before disposal and emphasis should be laid on reuse for waste reduction, reuse and recycling of waste to mitigate the problem of waste in our cities.
\end{abstract}

\section{DOI: https://dx.doi.org/10.4314/jasem.v23i9.10}

Copyright: Copyright (C) 2019 Chikwendu et al. This is an open access article distributed under the Creative Commons Attribution License (CCL), which permits unrestricted use, distribution, and reproduction in any medium, provided the original work is properly cited.

Dates: Received: 11 August 2019; Revised: 15 September 2019; 21 September 2019

Keywords: Aba, Comparative Study, Hotels, Solid waste, waste composition

Waste was an early problem of mankind, and a growing one that is of major concern to most nation of the world (Allende, 2009). Ogwueleka, (2004) reported that growing population, rising income and change in consumption pattern combine to complicate solid waste problem in Nigeria and especially urban centers, which has reached immense proportions as heap of refuse are found littered along major roads, river bank, gullies, gutters and open spaces. Factors responsible for the growth in waste generation in many modern societies are traced to increase population that is complimented by rapid urbanization and industrialization which has resulted to increase of waste generated. Other factors are tied to citizen's socio-economic status and the type of predominant commercial activities (David et al., 2014). In most developing cities, wastes are not properly collected and where proper collection is ensured, only a small fraction receives proper disposals. Urban waste management has been a challenge for municipalities and urban governments in the developing world, largely due to poor infrastructure, bureaucratic incompetence and limited institutional capacity of the municipalities.

Human beings are bound to produce waste, whether it is residential areas or work places. For the hospitality industries, the waste generated by daily operations is an ongoing challenge. Most of the hotel waste are generated from the kitchen (organic food waste, packaging, aluminum cans, glass bottles, corks and cooking oils), or from the housekeeping (cleaning materials) and plastic packaging. Waste is not only generated in guest rooms but also in public areas within the hotel, gardens (i.e. engine oils, pesticides, paints and preservatives to grass and hedge trimming and offices (toner cartridges, papers and cardboard waste). Refurbishment and renovation projects undertaken at the hotel contribute further to the waste management by the property (Tang, 2004).

Waste is a key concern in the hospitality industry; typically, a hotel guest can produce $1 \mathrm{~kg}$ of waste a day that accumulates to thousands of tons of waste annually (IHEL, 2002). Research have shown that $70 \%$ of hotel waste produced are biodegradable and get mixed with all other types of waste when dumped at the collection points. Some hotel waste produces greenhouse gases and others have significant health impact on humans and animals. The impacts of these wastes include: irritation to several organs of the body, emission of pungent odour and contamination of water bodies. The accumulation of these wastes provides breeding ground for disease vectors such as mosquitoes and flies (Kassim and Ali, 2006). This unpleasant development has led to some untimely 
human deaths, which was estimated to be up to 20,000 in a year (NEMA, 1998).

With all these problems and challenges in our society therefore, the objective of this study is to identify the quantity and composition of solid waste generated from hospitality industries as well as the management strategies in selected hotel in Abia State Nigeria.

\section{MATERIALS AND METHODS}

The research was carried out in Abia sate in south eastern Nigeria. It lies between latitudes $5^{\circ} 25^{\prime} 0^{\prime \prime} \mathrm{N}$, and longitude $7^{\circ} 30^{\prime} 0^{\prime \prime} \mathrm{E}$, it covers area of $6,320 \mathrm{~km}^{2}$ and a population of about $2,845,380$, it has two district seasons in a year, rainy season and dry season. The mean annual climatic data in Abia state are as follows; maximum and minimum temperature $25^{\circ} \mathrm{C}$ and $32^{\circ} \mathrm{C}$ respectively; rainfall $2400 \mathrm{~mm}$; relative humidity 80 $90 \%$ (NPC, 2006). Abia State has three major agro ecological zones, fresh water swamp forest, rainforest and derived savanna. (keay, 1989).

Information on solid waste composition and generation in selected hotels in Abia State, which involves the collection, sorting and weighing measurement of sorted waste was carried out once a week between 6:30 am and 8:00 am for a period of 4 months. Sorting of waste to determine the composition and generation rates in different hotels categories in specific locations in Umuahia and Aba, Abia State, Nigeria were ascertained. Quantities of solid waste composition generated from selected hotels at specific location (specifically in $\mathrm{kg}$ per day/week/month) at Umuahia and Aba, Abia State, Nigeria were recorded.

A $(9 \times 2)$ single factor experiment in randomized complete block design (RCBD) with three replicates was used to determine the waste types and quantities of municipal solid waste generated at specific location in each of the two municipalities/location (Umuahia and Aba) with three replications in both locations. Three hotels were randomly chosen at each location for waste generation collection and sorting within each site.

The composition and quantities of solid waste generated were weighed using weighing balance. The study was undertaken in three phases. The first phase of the study assessed solid waste composition and quantities of waste generated at different hotels in specific locations on weekly basis, the second phase of the study determined the type and quantities of waste generated at different hotels at specific locations on monthly basis, the third phase involves the quantities of waste types generated at different hotels selected for 16 weeks (4 months) in the study area. The results of the data collected were statistically analyzed using the procedures of Steel and Torrie (1980). Significant differences between treatment means of the various experiments were tested at $(\mathrm{P}<0.05)$, using the Fisher's Least Significant Difference (F-LSD) (Steel and Torrie, 1980; Alika, 2006).

\section{RESULTS AND DISCUSSION}

Table 1 shows that there is significant difference between the mean values of the various solid waste types generated in Umuahia and Aba, while there is no significant difference $(\mathrm{P}<0.05)$ in the levels of waste generated in the Hotels in Umuahia and a significant difference $(\mathrm{P}<0.05)$ between the mean level of waste generated in the hotels in Aba. This could be attributed to the level of commercial activities generated within and around the hotels especially in Aba city where numerous activities such as business activities, industries, ceremonies, institutions, etc. take place.

Table 2 shows that there was significant difference $(\mathrm{P}<0.05)$ between the mean values of the various solid waste types generated in Umuahia and Aba town in 4 weeks. There was also significant difference $(\mathrm{P}<0.05)$ between the mean values of the level of waste generated from the three hotels in Umuahia and Aba. From the result obtained, food/putrescible wastes are significantly higher compared to other hotel wastes followed by bottle/glass in weight on the mean of $(14.69 \mathrm{~kg}, 18.36 \mathrm{~kg})$ and $(13.60 \mathrm{~kg})(14.92 \mathrm{~kg})$ respectively while textile and inert waste are significantly low in hotels with mean of $(3.60 \mathrm{~kg}, 5.51$ $\mathrm{kg})$ and $(3.28 \mathrm{~kg}, 4.32 \mathrm{~kg})$ respectively in Umuahia and Aba.

Table 3 shows that there was no significant difference $(p<0.05)$ between means values of the various solid waste types generated and the level of waste generated in the three hotels under study in Umuahia. The result in the table also revealed that food/putrescible waste and glass/bottles are generated significantly higher than any other wastes types with mean values $(73.44 \mathrm{~kg}, \quad 59.89 \mathrm{~kg}) \quad 58.77 \mathrm{~kg}, \quad 54.61 \mathrm{~kg})$ and respectively in Aba and Umuahia city for 4 months of the study, followed by plastic and polybags with significant low in inert and textile waste with mean value of $(14.4 \mathrm{~kg}, 22.03 \mathrm{~kg})$ and $(13.12 \mathrm{~kg}, 17.28 \mathrm{~kg})$ in Umuahia and Aba location respectively.

Figure 2 shows that the highest waste component generated was from the food/putrescible with a mean value of $58.77 \mathrm{~kg}$ in Umuahia and $73.44 \mathrm{~kg}$ in $\mathrm{Aba}$, followed by the bottle/glass waste components with mean values of $54.61 \mathrm{~kg}$ in Umuahia and $59.89 \mathrm{~kg}$ in Aba in 16 weeks (4 month), while the least waste component was generated from inert and textile waste components with mean values of $13.12 \mathrm{~kg}$ and $14.40 \mathrm{~kg}$ 
in Umuahia respectively while in Aba the least waste types was generated was from papers and inert wastes with mean values of $13.56 \mathrm{~kg}$ and $17.28 \mathrm{~kg}$ respectively.

Table 1: Quantities of solid waste composition generated from selected hotels in Umuahia and Aba for (7 days)

\begin{tabular}{|c|c|c|c|c|c|c|c|c|}
\hline \multicolumn{5}{|c|}{ Hotels in Umuahia } & \multicolumn{4}{|c|}{ Hotels in Aba } \\
\hline $\begin{array}{c}\text { Waste composition } \\
(\mathrm{kg})\end{array}$ & $\begin{array}{l}1 \text { Star } \\
\text { Hotel }\end{array}$ & $\begin{array}{l}2 \text { Star } \\
\text { Hotel }\end{array}$ & $\begin{array}{l}3 \text { Star } \\
\text { Hotel }\end{array}$ & $\begin{array}{l}\text { Mean } \\
\mathbf{M} \pm \text { SE }\end{array}$ & $\begin{array}{l}1 \text { Star } \\
\text { Hotel }\end{array}$ & $\begin{array}{l}2 \text { Star } \\
\text { Hotel }\end{array}$ & $\begin{array}{l}\text { 3 Star } \\
\text { Hotel }\end{array}$ & $\begin{array}{l}\text { Mean } \\
\mathbf{M} \pm \text { SE }\end{array}$ \\
\hline Bottle/glass & 2.84 & 3.20 & 4.20 & $3.41 \pm 0.41$ & 2.55 & 3.22 & 5.46 & $3.74 \pm 0.88$ \\
\hline Poly bags & 1.21 & 1.80 & 3.21 & $2.07 \pm 0.59$ & 1.80 & 1.96 & 2.20 & $1.97 \pm 0.12$ \\
\hline Plastic/Rubber. & 2.00 & 2.50 & 2.40 & $2.30 \pm 0.15$ & 2.42 & 2.10 & 2.90 & $2.47 \pm 0.23$ \\
\hline Textiles & 0.30 & 0.60 & 1.80 & $0.90 \pm 0.49$ & 1.41 & 0.92 & 1.80 & $1.13 \pm 0.23$ \\
\hline Papers & 0.65 & 0.90 & 1.80 & $1.17 \pm 0.35$ & 0.58 & 0.85 & 1.11 & $0.84 \pm 0.15$ \\
\hline Metal & 0.76 & 0.94 & 1.65 & $1.17 \pm 0.27$ & 1.21 & 1.76 & 1.97 & $1.65 \pm 0.23$ \\
\hline Food/Putrescible & 4.82 & 3.80 & 2.40 & $3.67 \pm 0.70$ & 3.80 & 4.25 & 5.72 & $4.59 \pm 0.58$ \\
\hline Inert waste & 0.21 & 1.45 & 0.80 & $0.82 \pm 0.36$ & 0.70 & 1.11 & 1.43 & $1.08 \pm 0.21$ \\
\hline Others & 0.65 & 1.90 & 2.40 & $1.65 \pm 0.52$ & 0.87 & 1.30 & 2.00 & $1.39 \pm 0.33$ \\
\hline \multirow[t]{2}{*}{ Hotel means } & 1.49 & 1.90 & 2.30 & $1.90 \pm 0.23$ & 1.70 & 1.94 & 2.73 & $2.11 \pm 0.31$ \\
\hline & \multicolumn{2}{|c|}{ F-LSD (0.05 } & \multicolumn{2}{|c|}{ F-LSD (0.05) } & & & & \\
\hline Solid waste component & \multicolumn{2}{|c|}{1.2289} & \multicolumn{2}{|c|}{0.7546} & & & & \\
\hline Hotels & \multicolumn{2}{|l|}{0.7095} & \multicolumn{2}{|l|}{0.4355} & & & & \\
\hline
\end{tabular}

Table 2: Quantities of solid waste composition generated from selected hotels in Umuahia and Aba for (4 weeks)

\begin{tabular}{|c|c|c|c|c|c|c|c|c|}
\hline \multicolumn{5}{|c|}{ Hotels in Umuahia } & \multicolumn{4}{|c|}{ Hotels in Aba } \\
\hline Waste composition (kg) & $\begin{array}{l}1 \text { Star } \\
\text { Hotel }\end{array}$ & $\begin{array}{l}\text { Star } \\
\text { Hotel }\end{array}$ & $\begin{array}{l}3 \text { Star } \\
\text { Hotel }\end{array}$ & $\begin{array}{l}\text { Means } \\
M \pm S E\end{array}$ & $\begin{array}{l}1 \text { Star } \\
\text { Hotel }\end{array}$ & $\begin{array}{l}2 \text { Star } \\
\text { Hotel }\end{array}$ & $\begin{array}{l}3 \text { Star } \\
\text { Hotel }\end{array}$ & $\begin{array}{l}\text { Means } \\
M \pm \text { SE }\end{array}$ \\
\hline Bottle/glass & 11.36 & 12.80 & 16.80 & $13.65 \pm 1.63$ & 10.20 & 12.88 & 21.84 & $14.97 \pm 3.52$ \\
\hline Poly bags & 4.84 & 7.20 & 12.84 & $8.29 \pm 2.37$ & 7.20 & 7.84 & 8.80 & $7.95 \pm 0.46$ \\
\hline Plastic/Rubber & 8.00 & 10.00 & 9.60 & $9.20 \pm 0.61$ & 9.68 & 8.40 & 11.60 & $9.89 \pm 0.37$ \\
\hline Textiles & 1.20 & 2.40 & 7.20 & $3.60 \pm 1.83$ & 5.64 & 3.68 & 7.20 & $5.51 \pm 1.02$ \\
\hline Papers & 2.60 & 3.60 & 7.20 & $4.47 \pm 1.40$ & 2.32 & 3.40 & 4.44 & $3.39 \pm 1.08$ \\
\hline Metal scrap & 3.04 & 3.76 & 6.60 & $4.47 \pm 1.09$ & 4.84 & 7.04 & 7.88 & $6.59 \pm 0.91$ \\
\hline Food/Putrescible & 19.28 & 15.20 & 9.60 & $14.69 \pm 2.81$ & 15.20 & 17.00 & 22.88 & $18.36 \pm 2.32$ \\
\hline Inert waste & 0.84 & 5.80 & 3.20 & $3.28 \pm 1.43$ & 2.80 & 4.44 & 5.72 & $4.32 \pm 1.16$ \\
\hline Others & 2.60 & 7.60 & 9.60 & $6.60 \pm 2.08$ & 3.48 & 5.20 & 8.00 & $5.56 \pm 1.32$ \\
\hline \multirow[t]{2}{*}{ Hotel means } & 5.97 & 7.60 & 9.18 & $7.58 \pm 0.93$ & 6.82 & 7.76 & 10.93 & $8.50 \pm 1.24$ \\
\hline & \multicolumn{2}{|c|}{ F-LSD (0.05) } & \multicolumn{2}{|c|}{ F-LSD (0.05) } & & & & \\
\hline Solid waste types & \multicolumn{2}{|c|}{3.8278} & \multicolumn{2}{|c|}{3.2889} & & & & \\
\hline Hotels & \multicolumn{2}{|l|}{2.2090} & \multicolumn{2}{|l|}{1.8988} & & & & \\
\hline
\end{tabular}

Table 3: Quantities of solid waste composition generated from selected hotels in Umuahia and Aba for (16 weeks)

\begin{tabular}{|c|c|c|c|c|c|c|c|c|}
\hline \multicolumn{5}{|c|}{ Hotels in Umuahia } & \multicolumn{4}{|c|}{ Hotels in Aba } \\
\hline Waste composition (kg) & $\begin{array}{l}1 \text { Star } \\
\text { Hotel }\end{array}$ & $\begin{array}{l}\text { 2 Star } \\
\text { Hotel }\end{array}$ & $\begin{array}{l}3 \text { Star } \\
\text { Hotel }\end{array}$ & $\begin{array}{l}\text { Means } \\
\mathbf{M} \pm \text { SE } \\
\end{array}$ & $\begin{array}{l}1 \text { Star } \\
\text { Hotel }\end{array}$ & $\begin{array}{l}2 \text { Star } \\
\text { Hotel }\end{array}$ & $\begin{array}{l}\text { 3 Star } \\
\text { Hotel }\end{array}$ & $\begin{array}{l}\text { Means } \\
M \pm \text { SE } \\
\end{array}$ \\
\hline Bottle/glass & 45.44 & 51.20 & 67.20 & $54.61 \pm 6.51$ & 40.80 & 51.52 & 87.36 & $59.89 \pm 14.08$ \\
\hline Poly bags & 19.36 & 28.80 & 51.36 & $33.17 \pm 9.49$ & 28.80 & 31.36 & 35.20 & $31.79 \pm 1.86$ \\
\hline Plastic/Rubber & 32.00 & 40.00 & 38.40 & $36.80 \pm 2.44$ & 38.72 & 33.60 & 46.4 & $39.57 \pm 3.72$ \\
\hline Textiles & 4.80 & 9.60 & 28.80 & $14.40 \pm 7.33$ & 22.56 & 14.72 & 28.8 & $22.03 \pm 4.07$ \\
\hline Papers & 10.40 & 14.4 & 28.80 & $17.87 \pm 5.59$ & 9.28 & 13.60 & 17.76 & $13.56 \pm 2.45$ \\
\hline Metal & 12.16 & 15.04 & 26.40 & $17.87 \pm 4.35$ & 19.36 & 28.16 & 31.52 & $26.35 \pm 3.63$ \\
\hline Food/putrescible & 77.12 & 60.80 & 38.40 & $58.77 \pm 11.22$ & 60.80 & 68.00 & 91.52 & $73.44 \pm 9.28$ \\
\hline Inert waste & 3.36 & 23.20 & 12.80 & $13.12 \pm 5.73$ & 11.20 & 17.76 & 22.88 & $17.28 \pm 3.38$ \\
\hline Others & 10.40 & 30.40 & 38.40 & $26.40 \pm 8.30$ & 13.92 & 20.40 & 32.00 & $22.11 \pm 5.29$ \\
\hline \multirow[t]{2}{*}{ Hotel means } & 23.89 & 30.38 & 36.73 & $30.33 \pm 3.71$ & 27.27 & 31.01 & 43.72 & $34.00 \pm 4.98$ \\
\hline & \multicolumn{2}{|c|}{ F-LSD (0.05) } & \multicolumn{2}{|c|}{ F-LSD (0.05) } & & & & \\
\hline Solid waste types & \multicolumn{2}{|c|}{56.6380} & \multicolumn{2}{|c|}{13.1337} & & & & \\
\hline Hotels & \multicolumn{2}{|c|}{32.6999} & \multicolumn{2}{|c|}{7.5328} & & & & \\
\hline
\end{tabular}

This result is in line with the reports of Oyediran (1997) and Anyakaoha (1997) who noted that municipal waste in Nigeria contains several substances, including leaves, plastic containers, paper, food waste, glass, textile, metals, polythene, etc. According to Ogwueleka, (2009) growing population, rising income and changing consumption pattern combines to complicate solid waste problems in Nigeria. The result from the field experiment shows that there is significant difference $(\mathrm{P}<0.05)$ in solid waste components studied, food/putrescible wastes are generated more than any other type of waste with mean value of $3.67 \mathrm{~kg}$ in Umuahia and $4.59 \mathrm{~kg}$ in Aba within 7 days, $14.69 \mathrm{~kg}$ in Umuahia and $18.36 \mathrm{~kg}$ in Aba in a period of 4 weeks and $58.77 \mathrm{~kg}$ in Umuahia and $73.44 \mathrm{~kg}$ in Aba in 16 weeks. This is in line with the findings of Nwachukwu, (2010) which reveals that Nigerians traditionally use enormous quantities of 
assorted leaves of various plants for the fermentation, preparation, wrapping, storage, preservation and sale of other food stuff and these leaves account for a high portion of the disposed wastes (Shashikanta, 2015).
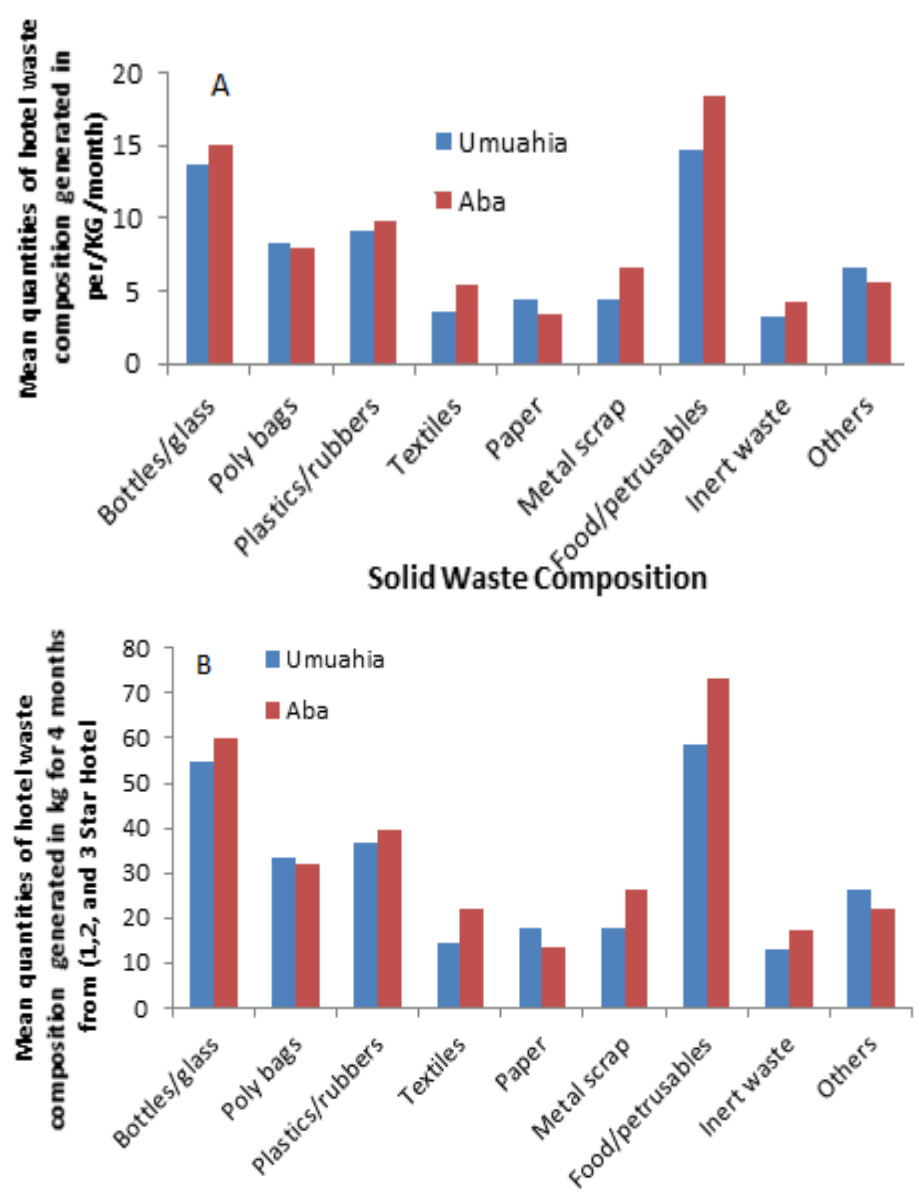

Solid waste composition

Fig. 2 Mean quantities of solid waste composition generated (A) per month and (B) in $\mathrm{kg}$ for 4 months (16 weeks) in selected hotels in Umuahia and Aba municipality.

More waste is generated in Aba metropolis, this could be attributed to the area been densely populated and being the industrial hub of the State with more commercial activities. These findings are in line with that of Iwuchukwu (1989), who revealed sources of the factors that influenced municipal waste generation to include human population growth of the municipalities' industrial development, diffusion of technical competence, proximity to waste disposal site, accessibility, transportation facilities and composition of the waste. Contreau (1982), revealed, also that the type and waste volume of waste generated vary according to the level of economic development of an area and that municipal dwellers in wealthy cities tends to generate greater waste than municipal dwellers in less wealthy cities.
Conclusion: This study has identified the composition/types of waste commonly found and quantities generated in hotels in Abia State. Food waste/putriscible followed by bottle/glass and plastics/ rubber had the highest quantities of waste generated in 6 hotels selected from 2 cities in Abia State (Umuahia and $\mathrm{Aba}$ ). The study recommend that waste should be sorted out into their various components at source before disposal and emphasis should be laid on reuse of waste reduction, reuse and recycling of waste to mitigate the problem of waste in our cities.

\section{REFERENCES}

Alika, JE (2006). Statistical and Research Methods $2^{\text {nd }}$ Edition Ambik press, Benin City, Nigeria, Pp366 
Allende, R (2009). Waste history in the Gambia. Thesis (M.Sc.), University of the Gambia.

Anyakaoha, EU (1997). Towards achieving effective waste generation and disposal in premises in Nigeria.

Cointreau SJ (1982). Environmental management of urban solid waste in developing countries: A project guide. Urban Development Technical Paper No 5. The World Bank, Washington, DC.

David, OO; Oladipupo, OA; Anthony, NE; Isaac, IA; Kolawole, OA (2014). Appraisal of municipal solid waste management. Its effects and resources potential in a semi urban city. Journal of south Afri Business Research DOI:10.5/71/2014.705695.

IHEL. (2002). Hotel care: Community Action and Responsibility for the Environment, London, UK. International Hotel Environment. Initiatives.

Iwuchukwu, JJ (1989). Planning for regional solid waste management system in Aba, Nigeria.

Kassim, SM; Ali, M (2006). Solid waste collection by the private sector: Households' perspective Findings from a study in Dar es Salaam city, Tanzania. Habitat International 30:769-780.

Keay, RWJ (1989). An outline of Nigeria vegetation. A revised edition of Nigerian trees. Laxendan press Oxford. pp.318-339.

NEMA. (1998). Caring for our Environment. A Handbook for Local Leaders, NEMA in Conjunction with Friedrich Ebert Stiffing (FES).

NPC. (2006). National population census report, Abuja: Federal Government of Nigeria.
Nwachukwu, MU (2010). Solid waste generation and disposal in a Nigeria City: anempirical analysis in Onitsha metropolis. J. Environ. Manage. Saf. 1, 180-191.

Ogwueleka, TC (2004). Planning model for refuse management. Journal of science and technology, 3 (2):71-76.

Ogwueleka, TC (2009). Municipal Solid Waste Characteristic and Management in Nigeria. Iran J. Environ. Health Sci. Eng. 6 (3):173-180.

Oyediran, AB (1997a). Waste Generation and Disposal in Nigeria: perspectives in environmental management. A key note addresses at the proceedings of next annual workshop 19911995. kraft books limited. Ibadan.

Oyediran, AB (1997b). Enhancing Environmental Protection in Nigeria through Environmental Education. A Paper Presented at the International Seminar on the Petroleum Industry and Nigeria Environment, Port-Harcourt.

Shashikanta, K (2015). A Review on the Recent Scenario of Municipal Solid Waste Management in India). International Journal of Engineering Research and General Science Volume 3, Issue 3: 528-542.

Steel, RGD; Torrie, JH (1980) Principles and Procedures of Statistics. A Biometric Approach, $2^{\text {nd }}$ Ed. Mc Graw-Hill book Company, New York. Pp 633.

Tang, J (2004). A Case Study of a Hotel Solid Waste Management Programmes in Bali, Indonesia. 